\title{
Apoptosis Inducing Activity of Bark Extract of Spathodea campanulata on Human Leukemia Cell Lines U937, K562 \& HL60 Cell Lines via Caspase Cascade
}

\author{
Shrawan Kumar ${ }^{1,2}$, Rahul Laxhman Gajbhiye ${ }^{1}$, Shila Elizabeth Besra ${ }^{1 *}$ \\ ${ }^{1}$ Central Instrumentation Facility and Cancer Biology \& Inflammatory Disorder Division, CSIR-Indian Institute of Chemical Biology, 4 Raja \\ S.C. Mullick Road, Kolkata, West Bengal, India. \\ 2University Department of Biotechnology, Vinoba Bhave University, Sindoor, Hazaribagh-Jharkhand, India. \\ *Corresponding author's E-mail: shilabesra@iicb.res.in
}

Received: 14-06-2020; Revised: 22-08-2020; Accepted: 30-08-2020.

DOI: $10.47583 /$ ijpsrr.2020.v64i01.022 \begin{abstract}
Spathodea campanulata plant has been traditionally used for many ailments. The anti-proliferative activity of bark extract of Spathodea campanulata (BESC) has been investigated against three human leukemic cell lines U937, K562 and HL-60 where IC 50 values are calculated to be $20.5 \mu \mathrm{g} / \mathrm{ml}, 19.45 \mu \mathrm{g} / \mathrm{ml} \& 20.14 \mu \mathrm{g} / \mathrm{ml}$ respectively whereas in RAW264.7 cells showed insignificant reduction in O.D. values than control. Morphologically, Cell shrinkage, membrane blebbing, chromatin condensation, nuclear fragmentation and formation of apoptotic bodies are characteristic a feature of apoptosis has been found on all the treated cells but not in control cells. Gel electrophoresis study shows fragmented DNA in the form of ladder and Flow cytometric analysis showed appreciable number of cells in early \& late apoptotic stages. A significant change in the mitochondrial membrane potential was observed in the BESC treated leukaemia cells with MMP shift assay. The cells are getting arrested in the sub- $\mathrm{G}_{1} \& \mathrm{G}_{1}$ phases of cell cycle. Activation of Caspase 9 and 3 and reduction in Caspase 8 confirms the apoptosis was mediated through intrinsic pathway activation.
\end{abstract}

Keywords: Spathodea campanulata Bark, Leukemia, Apoptosis, Caspase.

\section{INTRODUCTION}

$\mathrm{P}$ lant is a perfume of a pharmaceutical science. Plant has been a proven important source for the alleviation of various diseases of human beings since, from the archaic period. Leukemia refers to abnormal and uncontrolled proliferation of blood cells in the bone marrow due to genetic and epigenetic changes. In this disorder hematopoietic stem cell starts producing more immature WBC and replaced with normal WBC, resulting in the immune-compromised condition. Leukemia is one of the most common cancers in people over 55 years in the developed countries. It is estimated that 61,780 are the new cases of leukemia and 22,840 is leading to death. The latest figures show that the 5 -year survival rate for all subtypes of leukemia is $62.7 \%$ (US, $\mathrm{NCl}$ 2019). Only chemotherapy is an effective method for the treatment of malignant leukemia. Nowadays, several therapeutic approaches have been taken to beat the complexities of various cancers. The greatest disadvantage in the presently accessible potent artificial anti-cancer drugs lies in their toxicity, many side effects, and reappearance of symptoms after discontinuation ${ }^{1}$. Cytarabine (cytosine arabinoside, ARA-C) has been used for the remedy of acute myeloid leukemia (AML) for nearly 40 years ${ }^{2}$. Drug resistance one of the main obstacles of chemotherapy. In the case of ARA-C resistance can occur by several different mechanisms ${ }^{3}$. ARA-C is a prodrug that's triggered by phosphorylation by deoxycytidine (CdR) kinase. Because the human $\mathrm{CdR}$ kinase gene is placed on chromosome 4 , there are two copies of the gene in the cell ${ }^{4}$. Complete drug resistance due to a deficiency in CdR kinase is unlikely because it lacks the gene inactivation of both alleles. Another mechanism of drug resistance to ARA-C is due to an increase in the intracellular level of dCTP in leukemic cells ${ }^{5}$. To avoid this complication, it is necessary to use natural methods for the treatment of leukemia. Various types of plants are discussed in different folklore of medicines. Our plant of interest is Spathodea campanulata which has various medicinal effects. It is an African plant that is used in tropical and subtropical areas for ornamental purposes as well as for the treatment of various types of diseases ${ }^{6}$. However, Different parts of $S$. campanulata (leaf, bark, root, etc.) have been used against various types of disease ${ }^{7}$. Therefore, we evaluated the anti-leukemic activity of bark extract of Spathodea campanulata (BESC) against U937 (human leukemic monocytes lymphoma cell line), K562 (human myelogenous leukemia cell line) and HL60 (acute promyelocytic leukemia) cell line.

\section{MATERIAL AND METHODS}

\section{Chemicals}

The following chemicals were used: RPMI 1640 medium (Gibco, USA), Fetal bovine serum (FBS), HEPES, Lglutamine, Penicillin- Streptomycin (Bio-west, Germany), Gentamycin (Nicholas, India), Ara-C (ArabinofuranosylCytidine), MTT [3-(4,5-dimethylthiozol2-il)-2,5-2,5-dipheniltetrazoliumbromide], Ethidium bromide and Acridine orange, Annexin V- FITC apoptosis detection kit, RNase, Propidium iodide, were purchased from Sigma (St. Louis, MO, USA), Proteinase $k$ (SRL),Caspase-8,Caspase-9, Caspase-3(Bio-Vision), DMSO 
(dimethylsulphoxide),Chloroform, isoamyl alcohol, Methanol (Merk), and all other chemicals and reagents were of analytical grade and procured locally.

\section{Cell culture}

Three human leukemic cell lines U937, K562, HL60 \& RAW264.7 were purchased from the National Facility for Animal Tissue and Cell Culture, Pune, India. The cells were maintained in RPMI 1640 medium (Gibco, USA), supplemented with $10 \%$ heat inactivated $\mathrm{FCS}, 100 \mathrm{U} / \mathrm{ml}$ Penicillin (Biowest, Germany), and $100 \mathrm{mg} / \mathrm{ml}$ Streptomycin (Biowest, Germany). Cultures were maintained at $37^{\circ} \mathrm{C}$ in a humidified atmosphere containing $5 \% \mathrm{CO} 2$ in air. In all the experiments untreated leukemic cells were termed as control group.

\section{Plant Material}

The bark of Spathodea campanulata (family: Bignoniaceae) was collected from the park of Kasba, Gariahat, Kolkata, India in the month of May 2015. The bark of this plant was authenticated by Dr. V. P. Prasad, Scientist - D, Central National Herbarium, Botanical Survey of India, Ministry of Environment \& Forests, and Government of India at Howrah, West Bengal. A voucher specimen No is $\mathrm{CNH} / \mathrm{Tech}$. II/2015/30/309 was deposited in the Cancer Biology \& Inflammatory Disorder Division, CSIR, Indian Institute of Chemical Biology, Kolkata.

\section{Preparation of extracts}

The barks of Spathodea campanulata were harvested during dry season and air dried, then grinded into powder (200gm) and soaked in about $350 \mathrm{ml}$ petroleum ether (Merck) in room temperature and was repeated 2 times. Petroleum ether extract was obtained. Then, it was dissolved in $500 \mathrm{ml}$ of methanol (Merck) in room temperature for 7 days with occasional shaking. The extract was concentrated in a Buchi rotary evaporator at $40^{\circ} \mathrm{C}$ and stored at room temperature for further in-vitro study. The methanol free extract of Spathodea campanulata bark was yield $19.4 \mathrm{~g}$. Stalk solution was prepared as $1 \mathrm{mg} / \mathrm{ml}$ in PBS from here desired concentrations $(25,50,100,200 \mu \mathrm{g} / \mathrm{ml})$ was used for invitro experiments.

\section{Detection of Cytotoxicity by MTT assay}

U937, K562, HL60 \& RAW264.7 cells $\left(1 \times 10^{5}\right)$ were separately seeded in 96-well sterile plates for 24,48 and $72 \mathrm{hrs}$. All the treated cells were grown in humidified atmosphere containing $5 \% \mathrm{CO} 2$ in an incubator at $37^{\circ} \mathrm{C}$ and the untreated cells were considered as control. After desired incubation $20 \mu \mathrm{l}$ of MTT $(4-5 \mathrm{mg} / \mathrm{ml}$ in PBS as a stock solution) was added to each well and incubated again for 3 to 4 hrs at $37^{\circ} \mathrm{C}$. The MTT assay is a colorimetric assay for assessing the metabolic activity of the cells or cell viability of NADPH dependent cellular oxidoreductase enzymes and represents number of viable cells present. These enzymes are capable of reducing the tetrazolium dye MTT, which is yellow in colour, to insoluble purple colored formazan. The intensity of the colour was measured at $570 \mathrm{~nm}$ by micro-plate manager (Reader type: Model 680XR Bio-Rad Laboratories Inc.). The IC50 values were determined for the all the carcinoma cells.

\section{Morphological Studies for Detection of Apoptosis}

\section{Light Microscopy}

To investigate the effect of BESC on cell morphology $1 \times$ $10^{6}$ cells (U937 and K562) were seeded in RPMI media supplemented with $10 \%$ FBS. After $24 \mathrm{hrs,} \mathrm{the} \mathrm{cells} \mathrm{were}$ treated with $\mathrm{IC}_{50}$ dose of BESC and then the cells were then observed under a light microscope (Leica DMI 4000 B) at a magnification of $40 X$.

\section{Fluorescence Microscopy}

U937, K562 and HL60 cells $\left(1 \times 10^{6}\right)$ were treated with different IC50 doses of BESC(corresponding to each cell line) for $24 \mathrm{hrs}$ and observed using a fluorescence microscope for determining morphological changes. The untreated control cells and BESC treated cells were harvested separately (centrifuged at $1000 \mathrm{rpm}$ for $5 \mathrm{~min}$ ), the pellets were washed twice with PBS and then stained with $100 \mu \mathrm{g} / \mathrm{ml}$ of acridine orange (Sigma, USA) and $100 \mu \mathrm{g} / \mathrm{ml}$ of ethidium bromide (Sigma, USA)in a ratio of 1:1. The cells were then immediately mounted on slides and observed under a fluorescence microscope for the morphological determination of the cells undergoing apoptosis.

\section{Confocal Microscopy}

U937 and K562 cells $\left(1 \times 10^{6}\right)$ were treated with different $\mathrm{IC}_{50}$ doses of BESC for $24 \mathrm{hrs}$. After $24 \mathrm{hrs}$ the untreated control cells and BESC treated cells were harvested and washed with ice cold PBS. The cells were then stained with $10 \mu \mathrm{g} / \mathrm{ml}$ of Propidium iodide (Sigma) for $5 \mathrm{~min}$. After mounting on slides the cells were observed to determine the differences in nuclear morphology between the untreated and BESC treated leukemic cells under confocal laser scanning microscope (Leica TCS-SP2 system, Leica Microsystem, Heidelberg, Germany) installed with an inverted microscope (LeicaDM-7RB) ${ }^{8}$. Images for Propidium iodide was acquired from UV laser line using $450 \mathrm{~nm}$ band pass filter for UV for images.

\section{Agarose gel electrophoresis study}

U937, K562 and HL60 cells were treated with $\mathrm{IC}_{50}$ dose of BESC for $14 \mathrm{hrs}$ then cells were resuspended in $500 \mu \mathrm{l}$ of lysis buffer (50 mMTris- Hcl, pH -8.0, 10 mM EDTA, 0.5\% SDS), $100 \mu \mathrm{g} / \mathrm{ml}$ of proteinase $\mathrm{K}$ was added and incubation was done at $50^{\circ} \mathrm{C}$ for $1 \mathrm{~h}$ and $37^{\circ} \mathrm{C}$ overnight respectively. DNA extraction was done by following the general phenol-chloroform extraction procedure and kept at $20{ }^{\circ} \mathrm{C}$ overnight .After centrifugation, DNA precipitates were washed with $70 \%$ ethanol, dried and evaporated at room temperature and dissolved in TE buffer $(\mathrm{pH}$ 8.0) at 4 으 overnight. To detect the DNA fragments, the isolated DNA samples were electrophoresed overnight at $20 \mathrm{~V}$ in 
$1 \%$ Agarose gel and stained with ethidium bromide. DNA fragmentation was observed in UV transilluminator ${ }^{9}$.

\section{Mitochondrial membrane potential $(\Delta \psi \mathrm{m})$ assay}

U937 and K562 $\left(1 \times 10^{6}\right)$ cells were treated with BESC with desired dose and untreated as control for 24 hours to assay the mitochondrial membrane potential activity of cell in a flow cytometer. Cell were washed with PBS, pelleted down and eventually stained with JC-1 stain. The sample were incubated at $37{ }^{\circ} \mathrm{C}$ for $15 \mathrm{~min}$. Change in the mitochondrial membrane potential was determined by FACS (Becton Dickinson FACS Fortessa 4 leaser cytometer), Fluorescence detector equipped with $520 \mathrm{~nm}$ argon laser light source and $623 \mathrm{~nm}$ band pass filter (liner scale) with the help of BD FACS Diva software (Becton Dickinson).

\section{Apoptosis Assay}

In order to investigate the type of cell death induced by BESC, flow Cytometric analysis was done by performing dot plot assay. The U937 and K562cells (1x 106) were treated with individual IC 50 dose (18 hrs) of BESC for 18 hrs. The cells were centrifuged at $2000 \mathrm{rpm}$ for $8 \mathrm{~min}$ at $4^{\circ} \mathrm{C}$ and pelleted down. Then washed with Annexin-VFITC binding buffer provided in apoptosis kit (Sigma). Again, after centrifuging at $2000 \mathrm{rpm}$ at $4^{\circ} \mathrm{C}$, the cell pellets were dissolved in Annexin-V- FITC binding buffer containing Annexin-V- FITC and Propidium iodide. After 15 min incubation in dark at room temperature flow Cytometric analysis was done. All data were acquired with a Becton-Dickinson FACS LSR Fortessa 4 laser Cytometry. Flow-Cytometry reading was taken using 488 $\mathrm{nm}$ excitation and band pass filters of $530 / 30 \mathrm{~nm}$ (for FITC detection) and 585/42 nm (for PI detection). Live statistics were used to align the $X$ and $Y$ mean values of the Annexin-V FITC or PI stained quadrant populations by compensation. Data analysis was performed with BD FACS Diva software program ${ }^{10}$.

\section{Cell Cycle Arrest Study}

To assay the stage of cell cycle arrest in a flow cytometry, U937 and $\mathrm{K} 562\left(1 \times 10^{6}\right)$ cells were treated with BESC (IC 50 dose) for 18 hrs. Cells were washed with PBS, fixed with cold methanol. They were then resuspended in cold PBS and kept at $4{ }^{\circ} \mathrm{C}$ for $90 \mathrm{~min}$. Cells were pelleted down, dissolved in cold PBS, treated with RNase for 30 min at 37 ${ }^{\circ} \mathrm{C}$ and stained with Propidium iodide and kept in dark for $15 \mathrm{~min}$. Cell cycle phase distribution of nuclear DNA was determined on FACS (Becton Dickinson FACS Fortessa 4 laser cytometer), fluorescence detector equipped with $488 \mathrm{~nm}$ argon laser light source and $623 \mathrm{~nm}$ band pass filter (linear scale) using BD FACS Diva software (Becton Dickinson). ${ }^{10}$

\section{Caspase-8 Assay}

The assay was performed using a Caspase-8, Apoptosis Detection, Caspase-8/FLICE Colorimetric Bio-Assay Kit (Bio Vision), Cat.K113-100 according to the manufacturer's protocol. U937 cells $\left(1 \times 10^{7}\right)$ were treated with $\mathrm{IC}_{50}$ dose for $24 \mathrm{~h}$. The cells were pelleted down and resuspended in $50 \mu$ of cell lysis buffer (supplied with the kit) and incubated on ice for 10 min. After centrifuging at $10,000 \times \mathrm{g} 1$ minute, the supernatants (cytosolic extract) were transferred to fresh tubes and kept on ice and the caspase- 8 assay was performed according to the supplied kit protocol. $50 \mu \mathrm{l}$ of $2 X$ reaction buffer (containing $1 M$ DTT) was added to each sample. $5 \mu$ l of IETD-pNA substrate (4 $\mathrm{mM})(200 \mu \mathrm{M}$ final concentration) was added and incubation was done at $37{ }^{\circ} \mathrm{C}$ for 1-2 h. Absorbance was read at $405 \mathrm{~nm}$ and calculations were thereby done.

\section{Caspase-9 Assay}

The assay was performed using a Caspase-9, Apoptosis Detection, Colorimetric Bioassay Kit (R\&D Systems), Catalog No.BF10100 according to the manufacturer's protocol. U937 cells $\left(1 \times 10^{7}\right)$ were treated with $\mathrm{IC}_{50}$ dose for $24 \mathrm{~h}$. The cells were pelleted down and resuspended in $50 \mu$ of cell lysis buffer (supplied with the kit) and incubated on ice for 10 min. After centrifuging at $10,000 \times \mathrm{g}$ for 1 minute, the supernatants (cytosolic extract) were transferred to fresh tubes and kept on ice and the caspase- 9 assay was performed according to the supplied kit protocol. $50 \mu$ of $2 X$ reaction buffer (containing 1M DTT) was added to each sample. $5 \mu$ l of LEHD-pNA substrate (4 $\mathrm{mM})(200 \mu \mathrm{M}$ final concentration) was added and incubation was done at $37{ }^{\circ} \mathrm{C}$ for 1-2 h. Absorbance was read at $405 \mathrm{~nm}$ and calculations were thereby done.

\section{Caspase-3 Assay}

The assay was performed using a Caspase-3, Apoptosis Detection, Colorimetric Bio-Assay Kit (R\&D Systems), Catalog No.BF3100 according to the manufacturer's protocol. U937 cells $\left(1 \times 10^{7}\right)$ were treated with $\mathrm{IC}_{50}$ dose for $24 \mathrm{~h}$. The cells were pelleted down and resuspended in $50 \mu$ of cell lysis buffer (supplied with the kit) and incubated on ice for 10 min. After centrifuging at $10,000 \times \mathrm{g}$ for 1 minute, the supernatants (cytosolic extract) were transferred to fresh tubes and kept on ice and the caspase- 3 assay was performed according to the supplied kit protocol. $50 \mu$ of $2 X$ reaction buffer (containing 1M DTT) was added to each sample. $5 \mu$ l of DEVD-pNA substrate ( 4 $\mathrm{mM})(200 \mu \mathrm{M}$ final concentration) was added and incubation was done at $37{ }^{\circ} \mathrm{C}$ for 1-2 h. Absorbance was read at $405 \mathrm{~nm}$ and calculations were thereby done.

\section{Statistical Analysis}

Statistical analysis was done by Student's $t$-test. $P<0.05$ was considered as significant.

The percentage cell inhibition was calculated by the following formula: $-\%$ Cell inhibition $=100 \times$ (O.D of 
control- O.D of treated)/O. D of control O. D= Optical Density.

The percentage cell viability was calculated by the formula: - Viable cells $(\%)=($ Total number of viable cells per $\mathrm{ml} /$ Total number of cells per $\mathrm{ml}) \times 100$.

\section{RESULTS AND DISCUSSION}

\section{Detection of Cytotoxicity by MTT assay}
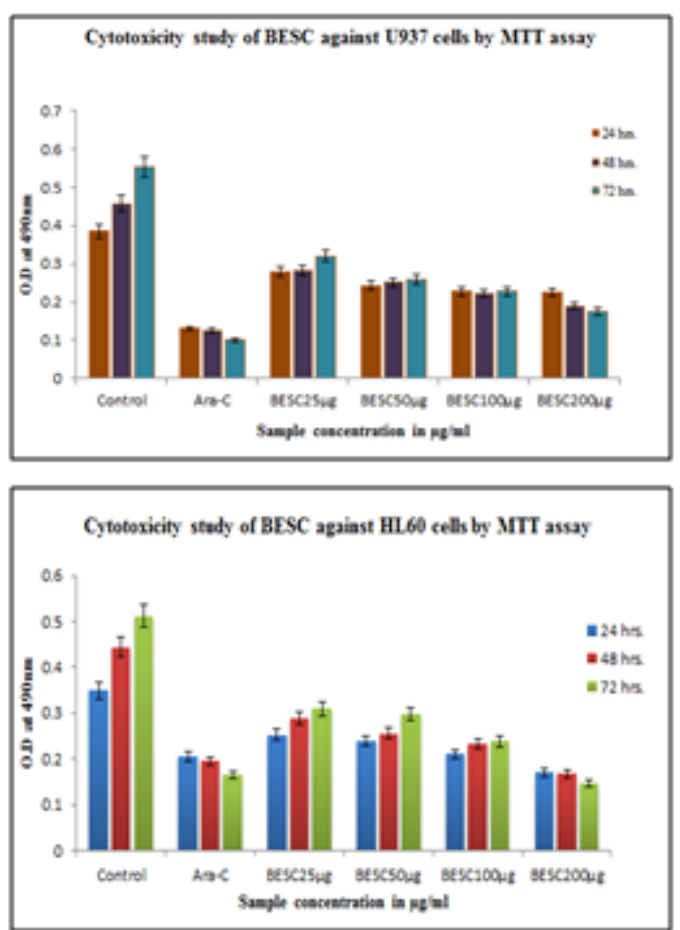

MTT assay of BESC showed very convincing cytotoxic effect on all the leukemic cell lines U937, K562, HL60 \& RAW264.7. The OD value is progressively decreasing with time $(24,48 \& 72 \mathrm{hrs}$.) and the concentration dependent manner of $\operatorname{BESC}(25,50,100$, and $200 \mu \mathrm{g})$. The IC 50 value of BESC treatment for $24 \mathrm{hrs}$ were calculated to be $20.5 \mu \mathrm{g} / \mathrm{mL}$ for U937, $19.45 \mu \mathrm{g} / \mathrm{mL}$ for $\mathrm{K} 562$ and $20.14 \mu \mathrm{g} / \mathrm{mL}$ for HL60 cells respectively.
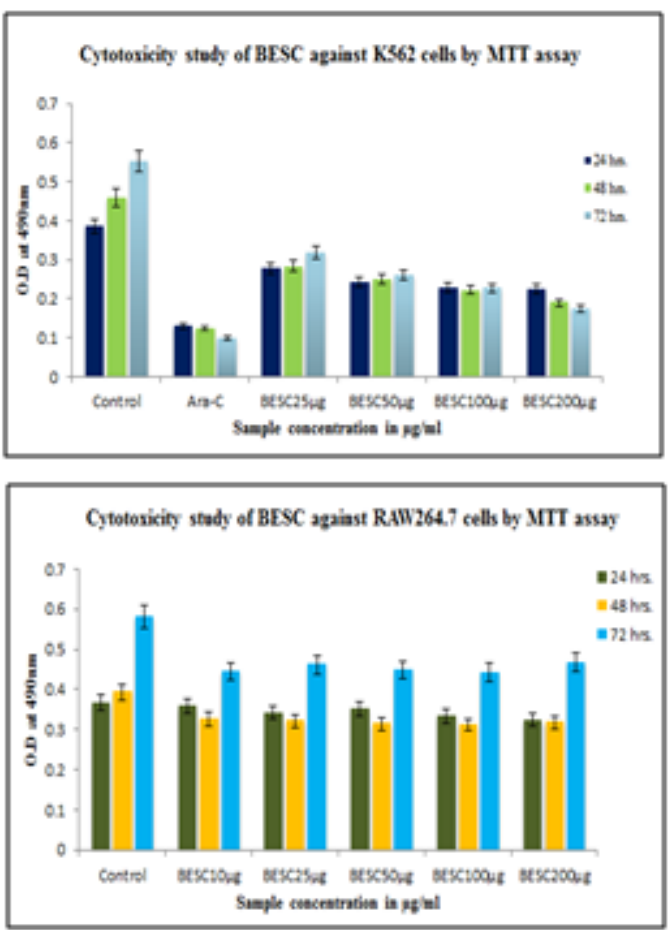

Figure 1: Histogram showing the significant decrease in OD value of U937, K562, HL60 \& RAW264.7 cells after treating with BESC than control. BESC treated cells showing progressively increase in \% of inhibition with time and concentration. The $\mathrm{IC}_{50}$ value of treated cells for $24 \mathrm{hrs}$ was calculated to be $20.5 \mu \mathrm{g} / \mathrm{mL}$ for $U 937,19.45 \mu \mathrm{g} / \mathrm{mL}$ for $\mathrm{K} 562$ and $20.14 \mu \mathrm{g} / \mathrm{mL}$ for HL60 cells respectively.

\section{Morphological study by Light and Fluorescence Microscope}

Light microscopic images clearly showed the membrane disintegration on $\mathrm{U} 937$ and K562 cells treated with BESC compared to that of untreated (control) cells. U937, K562 and HL60 was treated with BESC with $\mathrm{IC}_{50}$ value for the stained with ethidium bromide and acridine orange (colour-red or orange), investigate the presence of apoptotic cells (early and late) as compared to the

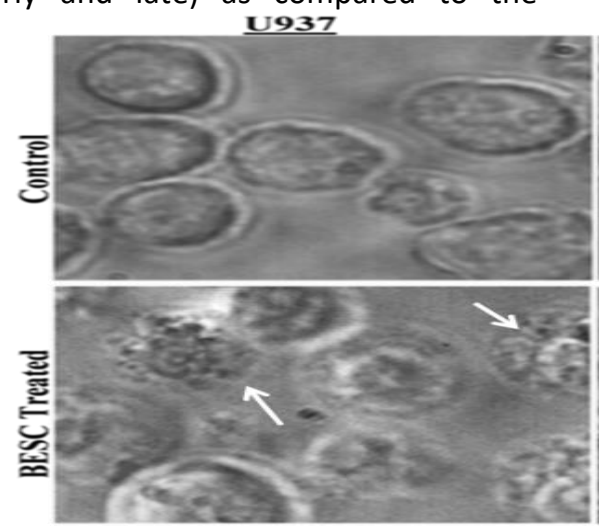

untreated control cells stained with only acridine orange (colour-green). In this study nuclear changes were observed including chromatin condensation and apoptotic body formation that indicate the occurrence of apoptosis. BESC induced apoptotic changes in both the leukemic cells. After $24 \mathrm{hrs}$ of treatment showing chromatin disintegration and formation of apoptotic bodies whereas the untreated cells have with intact nuclei.

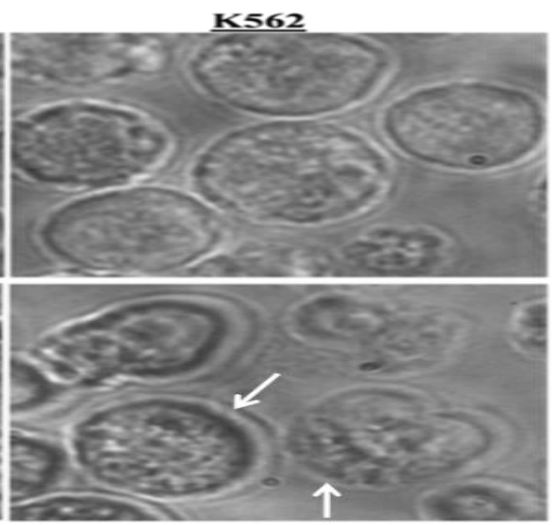

Figure-A 
Figure B
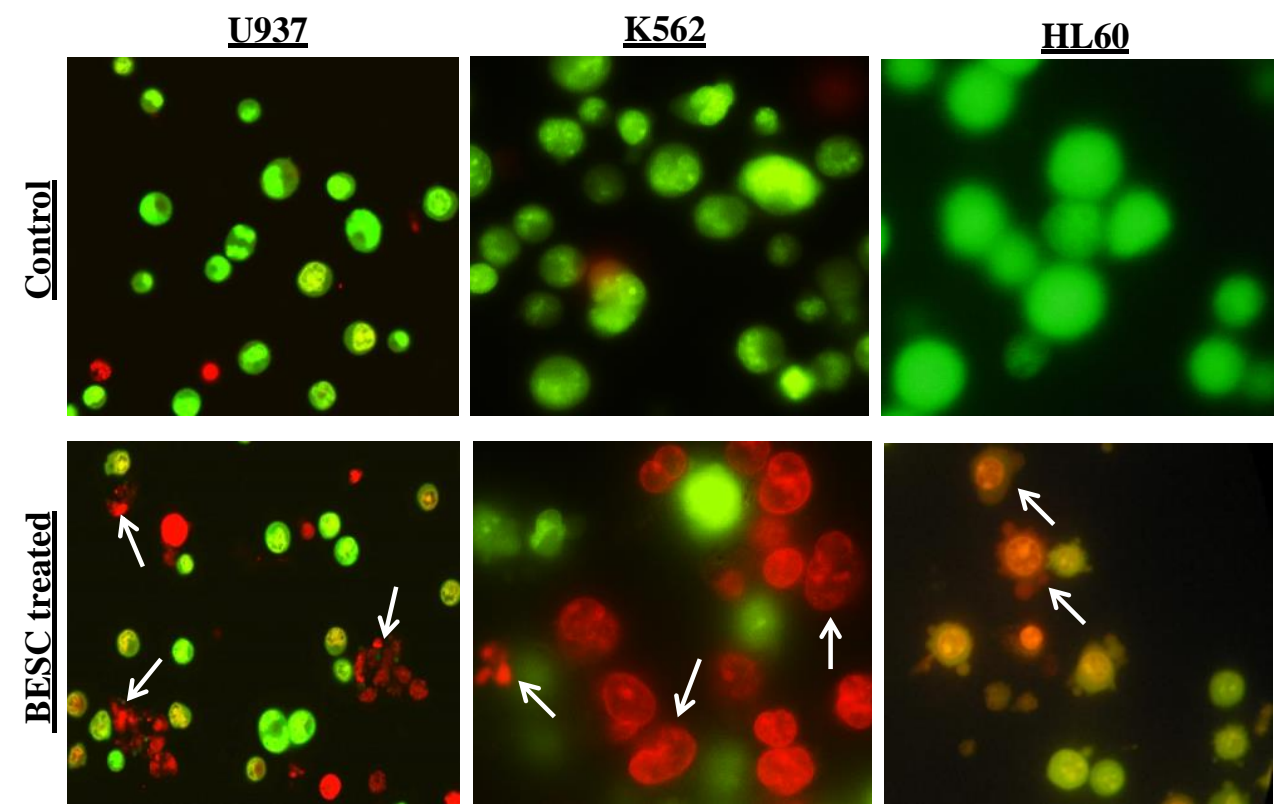

Figure 2: A. Showing the light microscopic images of control vs treated cell line of U937 and $\mathrm{K} 562$ with $\mathrm{IC}_{50}$ dosage. The Untreated (control) cells show intact morphology whereas the treated cells show distorted morphology and membrane disintegration. Fig.:2. B. Showing Fluorescence microscopic images of control vs treated cell line of U937, K562and HL60 with IC 50 dosage. The Untreated (control) cells shows intact morphology and gives bright green fluorescence whereas the treated cells show distorted morphology due to fragmented nuclei which ensure the apoptosis.

\section{Morphological study by confocal Microscope}

BESC shows a potent anti-leukemic effect after 24 hrs of treatment. Which showed the disintegration of nuclei and
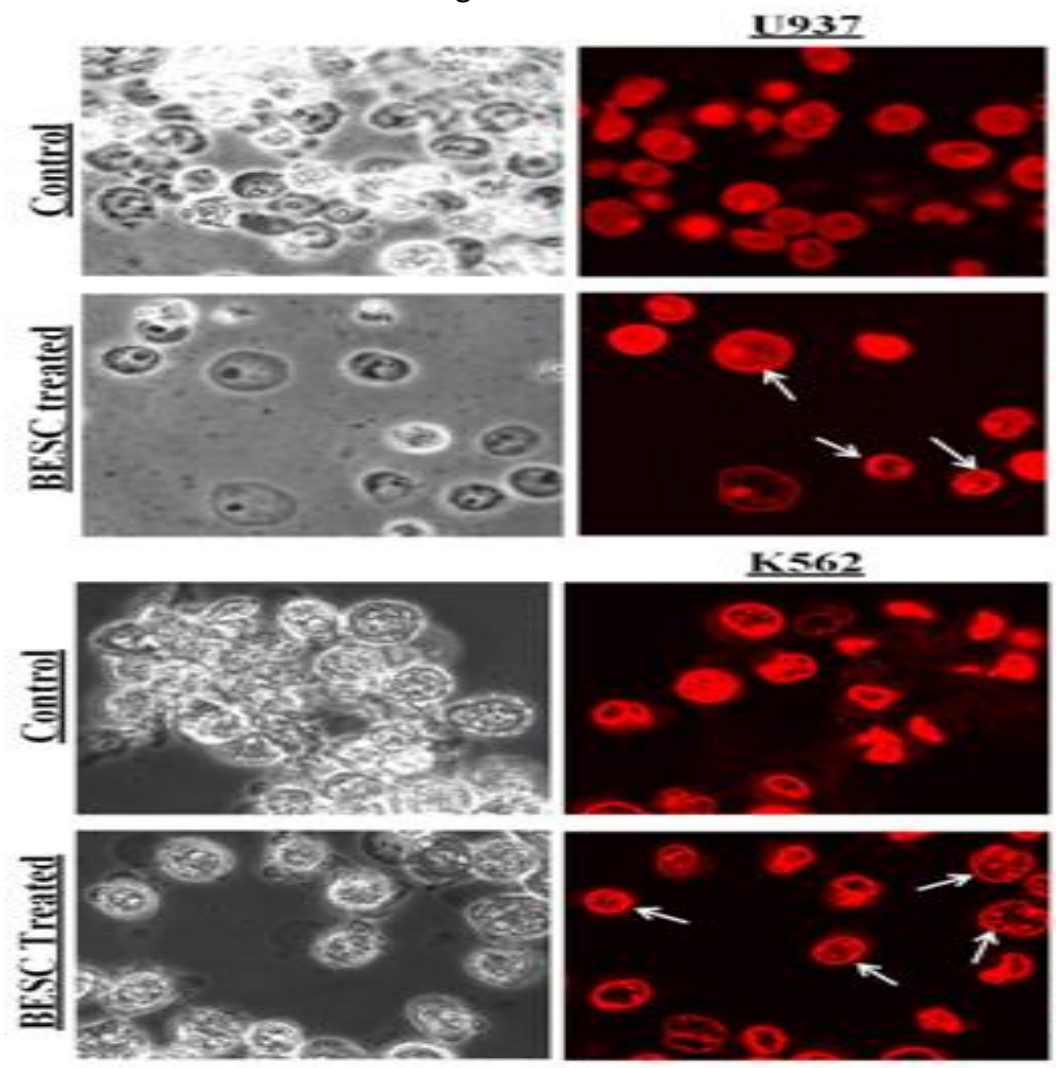

\section{$\mathbf{K} 562$}
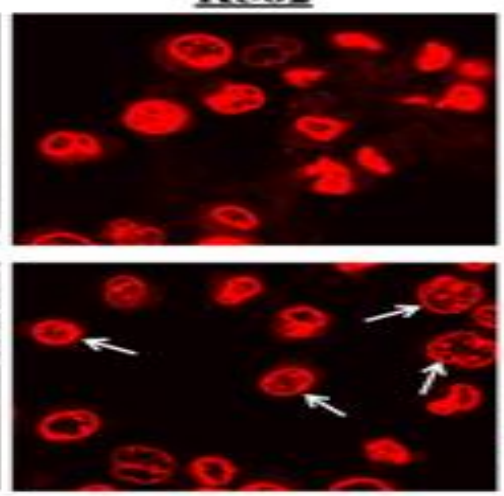
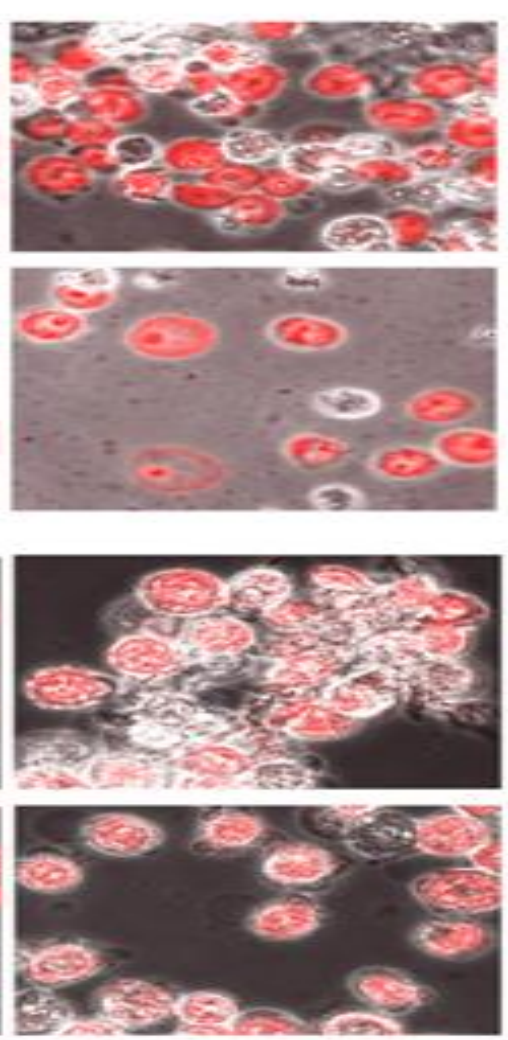

Figure 4: Showing Confocal microscopic images of control vs treated cell line of U937 and K562 with IC 50 dosage. The Untreated (control) cell shows intact morphology whereas the treated cells show distorted morphology due to fragmented nuclei and formation of apoptotic body take place. The cells were stained with PI.

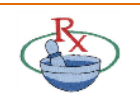




\section{Agarose gel electrophoresis study}

The DNA samples were isolated from both treated as well as untreated cells. The untreated (control) cells show intact DNA (lack cleavage) of U937, K562 and HL60.Whereas treated cells showed fragmented DNA of U937, K562 and HL60 on agarose gel. This simply indicates that BESC showing apoptotic activity in U937 and $\mathrm{K} 562$.

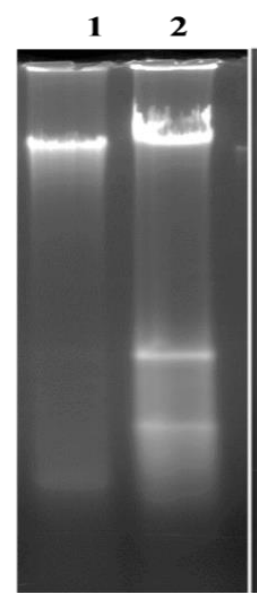

$\underline{\mathbf{U 9 3 7}}$

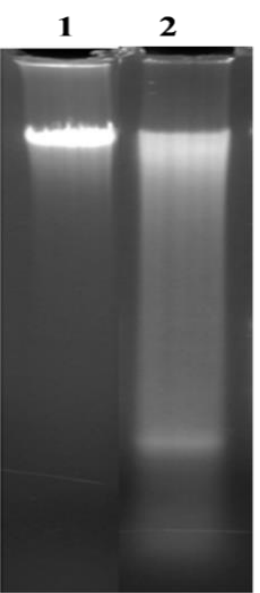

$\underline{\mathbf{K 5 6 2}}$

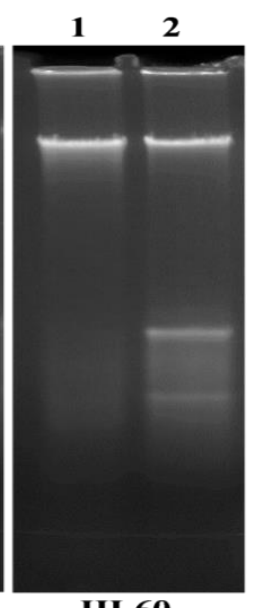

HL60 represents control of $\mathrm{U} 937$ and $\mathrm{K} 562$ respectively. Lane 2 represents $\mathrm{BESC}$ with $\mathrm{IC}_{50}$ dosage on $\mathrm{U} 937$ and $\mathrm{K} 562$ cell line respectively.

\section{Detection of mitochondrial membrane potential $(\Delta \psi \mathrm{m})$ assay}

Disruption of mitochondrial membrane potential is a very important parameter for the induction of apoptosis. The U937 and K562 cell lines when treated with desired dose of BESC, showed a loss of Mitochondrial Membrane Potential $(\Delta \psi \mathrm{m})$. The JC-1 stain cannot persist in the mitochondria of the apoptotic cells, as the mitochondrial membrane potential collapses, hence showing green fluorescence (P4) denotes apoptotic cells and red fluorescence (P3) denoting healthy cells where JC-1 stain persist. Depolarization in mitochondrial membrane potential was observed by staining untreated and treated cell by JC-1 dye. It led to shift from red to green fluorescence leading to the release of Cytochrome C. A efficient transmembrane shift of $9.3 \%$ to $44.9 \%$ and $9.9 \%$ to $49.8 \%$ were observed when U937 and K562 cells were treated with the $\mathrm{IC}_{50}$ value of $\mathrm{BESC}$ for 24 hours respectively.

Figure 5: showing agarose gel images of control vs treated cell line of U937,K562and HL60 with IC 50 dosage. Lane 1

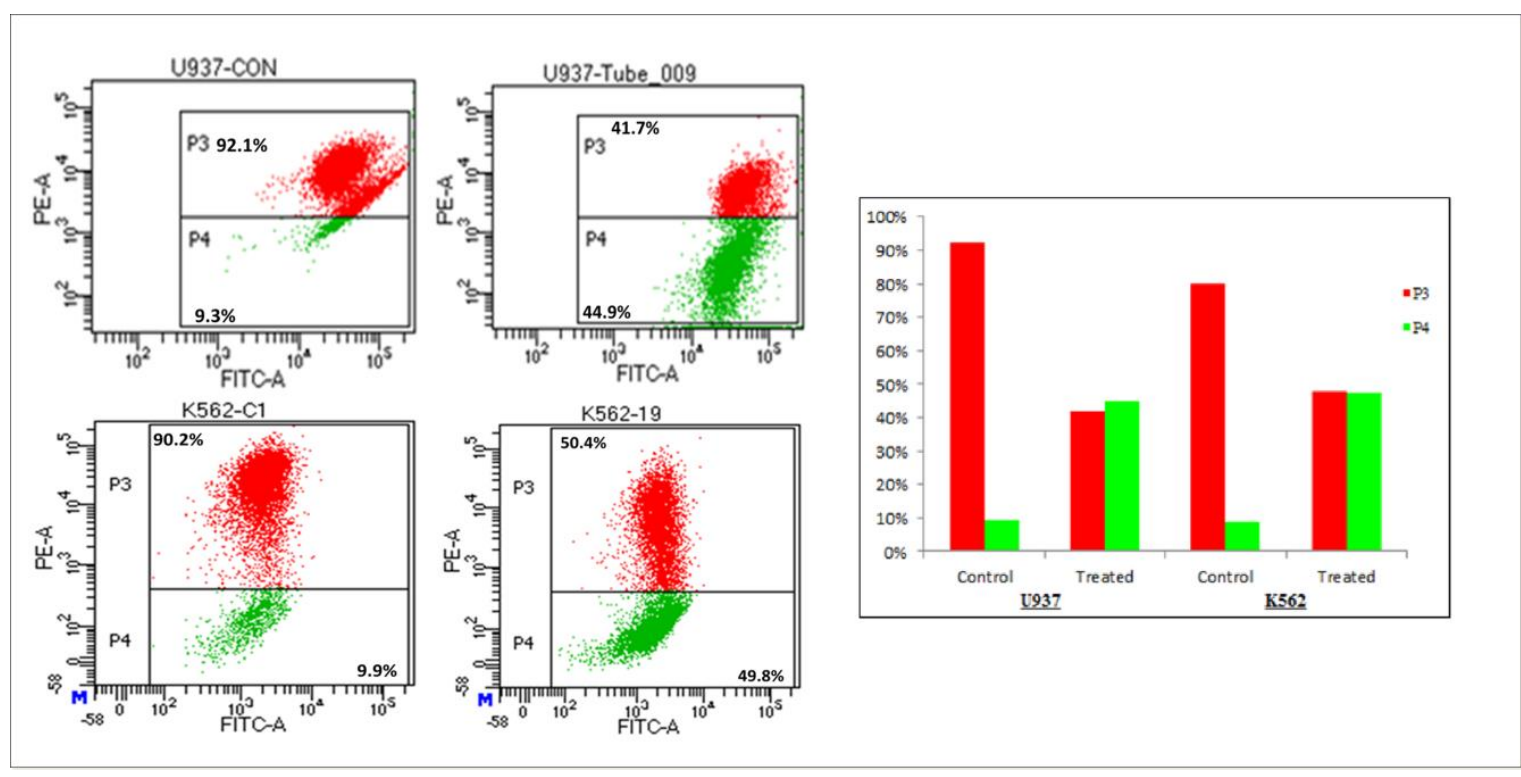

Figure 6: Flow cytometric analysis of mitochondrial membrane potential $(\Delta \psi \mathrm{m})$ on U937 and K562 cell line in both control and BESC treated cells respectively after $24 \mathrm{hrs}$ of treatment. A significant shift red to green fluorescence was observed in U937 and K562 cells.

\section{Detection of Apoptosis by Flow Cytometry}

In the flow cytometric analysis, double labelling technique, using annexin V FITC and propidium iodide, was utilized. Lower left (LL) quadrant (annexin V-/PI-) is regarded as the population of live cells, lower right quadrant (LR) (annexin V+/PI-) is considered as the cell population at early apoptotic stage, upper right (UR) quadrant (annexin $\mathrm{V}+/ \mathrm{PI}+$ ) represents the cell population at late apoptotic stage and extreme upper right (UR) \& upper left (UL) quadrant (annexin $\mathrm{V}-/ \mathrm{PI}+$ ) is considered as necrotic cell population. Flow cytometric data analysis revealed that after $24 \mathrm{~h}$ of treatment with desired dose of BESC for quantification of apoptosis was observed for U937 $0.3 \%$ against $42.2 \%$ and for $\mathrm{K} 5621.1 \%$ against $5.3 \%$, cells were in lower right quadrant which implies early apoptotic stage thereby, showing apoptotic inducing property of BESC on $\mathrm{U} 937$ and $\mathrm{K} 562$. 

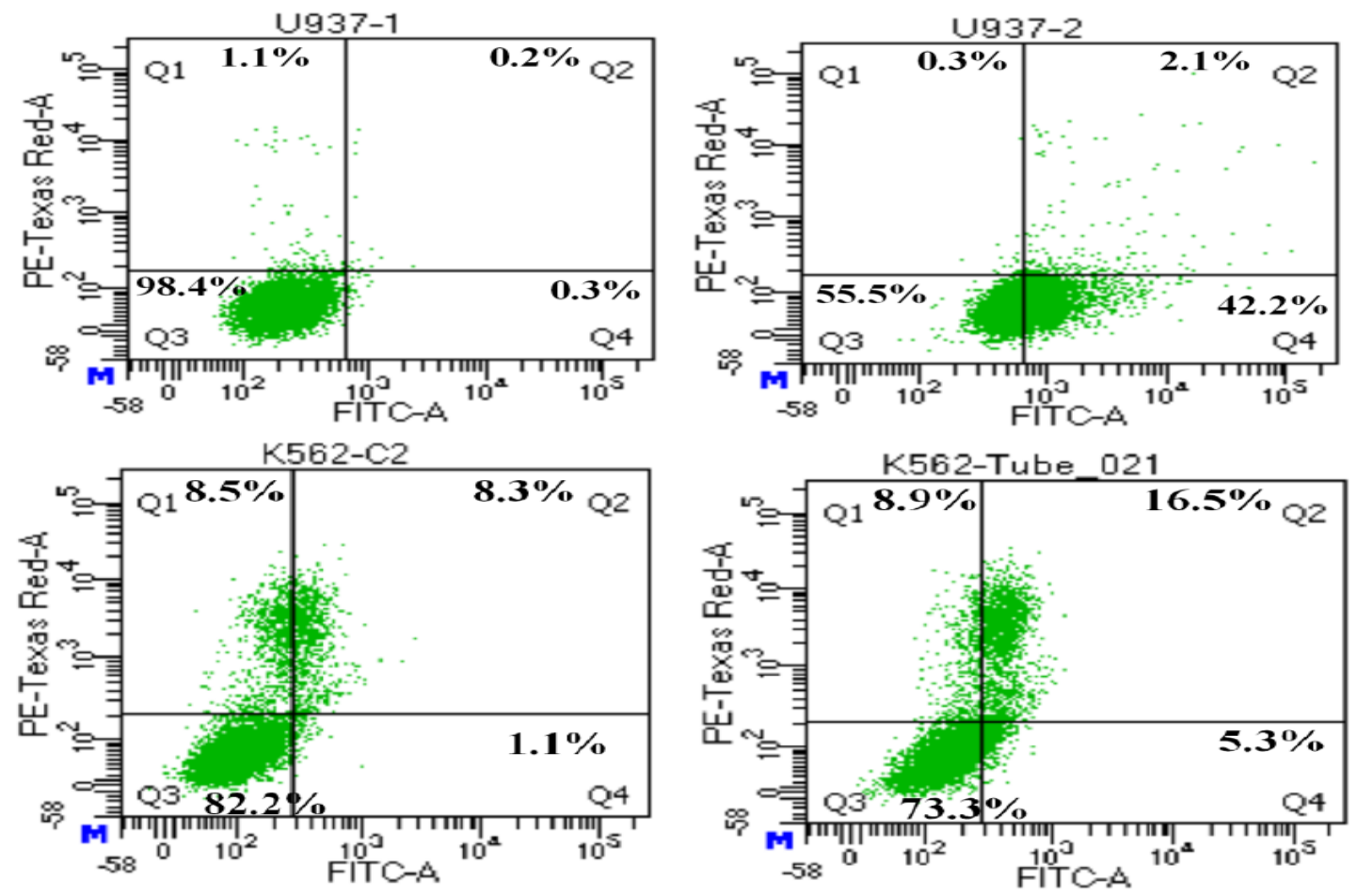

Figure 7: Flow cytometric analysis of untreated control and BESC treated of U937 and K562 cells stained with Annexin V FITC and propidium iodide. Dual parameter dot plot of FITC fluorescence ( $x$-axis) vs PI-fluorescence ( $y$-axis) shows logarithmic intensity.

\section{Study of Cell Cycle Arrest by Flow Cytometry}

Flow cytometric evaluation showed that after $24 \mathrm{hrs}$ treatment of U937 cell line DNA content increased in G1 phase (64.2\% against $45.9 \%)$. In case of $\mathrm{K} 562$ cell line DNA content increased in G1 phase (67.5\% against 53.2\%).This observation demonstrate that BESC significantly inhibited the growth of K562 and U937 cell line by arresting the cell populations in the sub-G0/G1 as well as G2/M phase of the cell cycle.
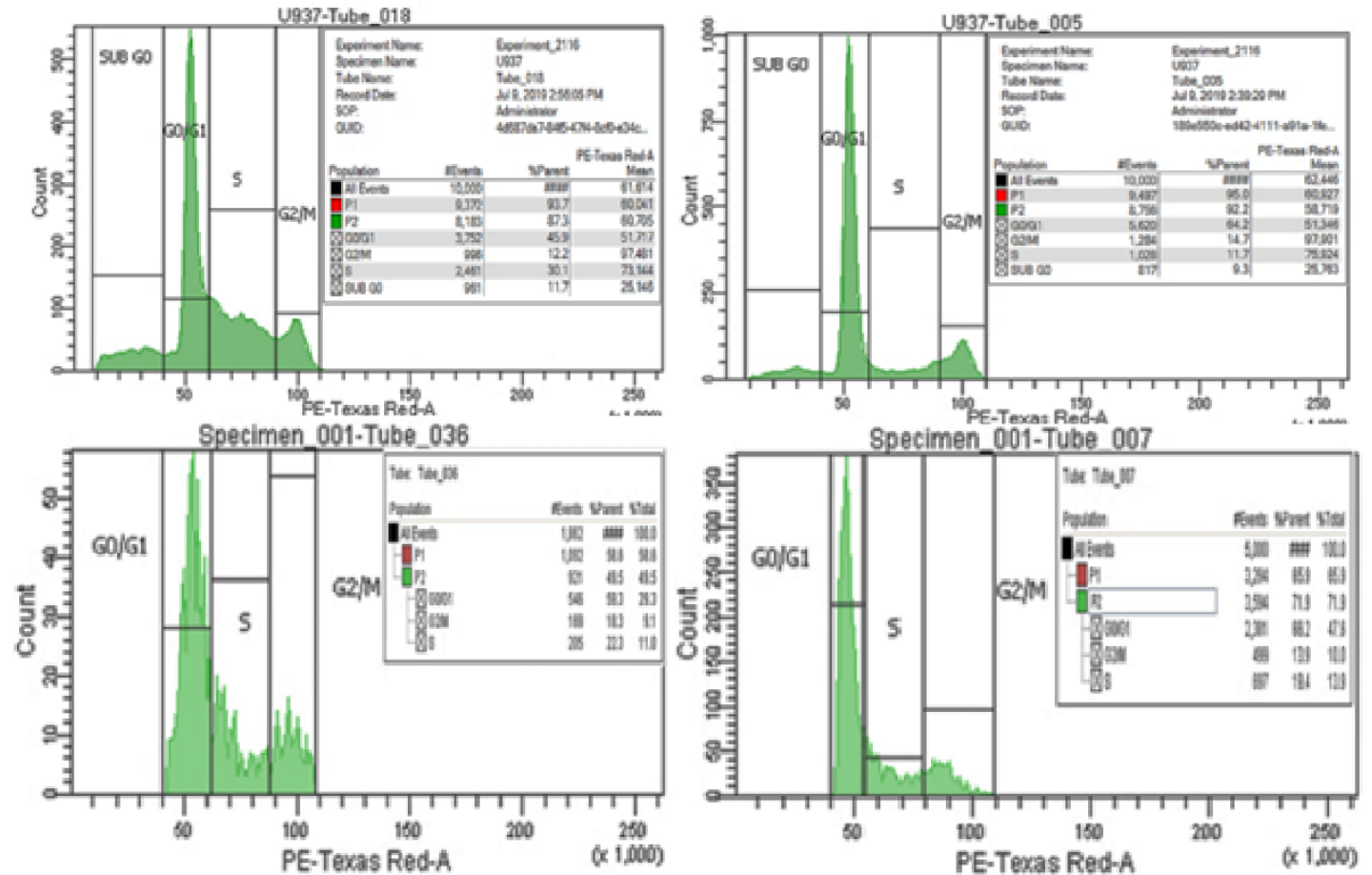

Figure 8: Flow cytometric evaluation of cell cycle phase distribution in controls and treated BESC at IC50 dosage on U937\& K562 cell after 24 hrs of treatment. Histograms represent various contents of DNA with actual number of cells (xaxis denotes fluorescence intensity of PE-Texas red and $y$-axis denotes count. 


\section{Caspase-8}

Caspases are a family of proteases that play a key role in cellular process in apoptosis. To investigate whether treatment with BESC induced apoptosis via extrinsic pathway, caspase-8 assays were performed in U937 cells. The experiments revealed insignificant change in the caspase- 8 activity in the extract of BESC treated with IC50 dose, as compared with that of the untreated control U937 cells. (Fig.9), supporting the fact that apoptosis induced by BESC treatment might not be mediated through the extrinsic pathway.

\section{Caspase -9 assay}

To investigate whether treatment with BESC induced apoptosis via intrinsic pathway, caspase- 9 assays were performed in 4937 cells. It shows significant change caspase- 9 activity that suggests BESC induce might be via intrinsic pathway.

\section{Caspase-3 assay}

To investigate whether treatment with BESC induced apoptosis via intrinsic pathway, caspase-3 assays were performed in $U 937$ cells. It shows significant change caspase- 3 activity that suggests BESC induce might be via intrinsic pathway.


Figure 9: Effect of BESC treatment on Caspase activity in U937 cells after $24 \mathrm{hrs}$ at IC50 dose with respect to control. The activity of caspase- 8 is decreases which suggest apoptosis induced by BESC treatment might not be mediated through the extrinsic pathway. Whereas in caspase-3 and 9 acivity is increases which show BESC treatment follow the intrinsic pathway.

\section{CONCLUSION}

The present investigations confirmed that methanolic extract of bark extract of Spathodea campanulata (BESC) shows significant effect on leukemic cells (monocytes lymphoma, myelogenous leukemia and, acute promyelocytic leukemia_cells) by triggering programmed cell death but it shows insignificant and non- apoptotic activity against normal murine macrophage cells (RAW264.7). Therefore, BESC efficiently shows the cytotoxic effect on human leukemia cell line via Caspase activation. So, from these studies it can be considered as a potent anti-leukemic agent for treatment of leukemia with minimum side effects. Further, more studies should be done and identify the active compound as well as to identify the signal transduction pathways in Spathodea campanulata for the treatment of various types of chronic diseases that will be beneficial for the human society.
Acknowledgement: The authors are very grateful to Indian Institute of Chemical Biology, Kolkata for providing facilities to perform the work. The authors are also thankful to CSIR for providing the necessary funding for the project.

\section{REFERENCES}

1. Roy S, Deb N, Basu S, Besra SE., Apoptotic activity of ethanolic extract of Moringa oleifera root bark on human myeloid leukemia cells via activation of caspase cascade, World J Pharm Sci., 3, 2014, 1138-56.

2. Lowenberg B, Downing JR, Burnett A., Acute myeloid leukemia, New England Journal of Medicine, 341, 1999, 1051-62.

3. Momparler RL, Onetto-Pothier N. In: kessel D, ed., Resistance to Antineoplastic Drugs, Boca Raton: CRC Press, 1998; 353-367.

4. Flasshove M, Strumberg D, Ayscue L, Mitchell BS, Tirier C, Heit W, Seeber S, Schütte J., Structural analysis of the deoxycytidine kinase gene in patients with acute myeloid 
leukemia and resistance to cytosine arabinoside, Leukemia, 8, 1994, 780.

5. Momparler RL, Chu MY, Fischer GA., Studies on a new mechanism of resistance of $\mathrm{L} 5178 \mathrm{Y}$ murine leukemia cells to cytosine arabinoside, Biochimica et Biophysica Acta (BBA)-Nucleic Acids and Protein Synthesis, 161, 1968, 48193.

6. Queiroz AC, Contrera FA, Venturieri GC., The effect of toxic nectar and pollen from Spathodea campanulata on the worker survival of Melipona fasciculata Smith and Melipona seminigra Friese, two Amazonian stingless bees, Sociobiology, 61, 2014, 536-40.
7. Wagh AS, Butle SR., Plant profile, phytochemistry and pharmacology of Spathodea campanulata p. Beauvais (african tulip tree): a review, IJPPS, 10, 2018, 0975-1491.

8. Herrmann M, Lorenz HM, Voll RE, Grünke M, Woith W, Kalden JR., A rapid and simple method for the isolation of apoptotic DNA fragments, Nucleic acids research, 22, 1994, 5506.

9. Roya S, Besra SE, De T, Banerjee B, Mukherjee J, Vedasiromoni JR., Induction of apoptosis in human leukemic cell lines U937, K562 and HL-60 by Litchi chinensis leaf extract via activation of mitochondria mediated caspase cascades, The Open Leukemia Journal, 1, 2008.

10. Jacobson MD, Weil M, Raff MC., Programmed cell death in animal development, Cell, 88, 1997, 347-54.

Source of Support: None declared.

Conflict of Interest: None declared.

For any question relates to this article, please reach us at: editor@globalresearchonline.net

New manuscripts for publication can be submitted at: submit@globalresearchonline.net and submit_ijpsrr@rediffmail.com 